\title{
Pemahamam Materi Hak Asasi Manusia dan Perilaku Kekerasan dengan Kesadaran Hukum Siswa
}

\author{
Siti Kamijah ${ }^{1}$, Sri Rahayu Pudjiastuti ${ }^{2 *}$, Mohamad Sutisna ${ }^{2}$ \\ ${ }^{I}$ SMK Tunas Multi Raya, Indonesia \\ ${ }^{2}$ STKIP Arrahmaniyah, Indonesia
}

\begin{abstract}
Abstrak-Sikap dan perilaku yang kurang mencerminkan kesadaran hukum Hak Asasi Manusia (HAM) yaitu dengan melakukan perilaku kekerasan fisik, serta kekerasan psikis sesama teman sehingga tak jarang memicu terjadinya perkelahian. Rendahnya kesadaran hukum siswa akan HAM dapat dilihat dari pemahaman siswa pada materi HAM yang masih rendah. Penelitian ini bertujuan untuk memperoleh data empiris mengenai hubungan pemahaman materi HAM dan perilaku kekerasan dengan kesadaran hukum.Penelitian ini dilaksanakan selama 3 bulan dari bulan Juli sampai bulan September 2020. Metode yang digunakan adalah metode korelasi. Jumlah sampel sebanyak 70 siswa. Penelitian ini menyimpulkan: (1) terdapat hubungan positif yang sangat signifikan antara pemahaman siswa tentang HAM dengan kesadaran hukum dengan koefisiensi korelasi $\mathrm{r}_{\mathrm{yx} 1}$ sebesar $0,9579(\alpha=0.05)$; (2) terdapat hubungan positif yang sangat signifikan anatara perilaku kekerasan dengan koefisiensi korelasi $\mathrm{r}_{\text {yx2 }}$ sebesar $0,8147(\alpha=0.05)$; (3) terdapat hubungan positif dan sangat signifikan antara pemahaman siswa tentang HAM dan perilaku kekerasan secara bersama sama dengan kesadaran hukum dengan koefisian korelasi $R_{\mathrm{yx} 1 \times 2}$ sebesar 0,9598 ( $\left.\alpha=0.05\right)$. Kontribusi pemahaman siswa tentang HAM dan perilaku
\end{abstract}

Kata kunci:

Pemahaman HAM,

Perilaku Kekerasan,

Kesadaran Hukum.

\section{Histori:}

Dikirim: 7 Maret 2021

Direvisi: 10 Maret 2021

Diterima: 14 Maret 2021

Online: 18 Maret 2021 kekerasan dengan kesadaran hukum sebesar 91,9\%.

(C)2021 JCC. All rights reserved (c) () () Author(s) agree that this article remains permanently open access under the terms of the Creative Commons Attribution-ShareAlike 4.0 International License

\section{Identitas Artikel:}

Kamijah, S., Pudjiastuti, S. R., \& Sutisna, M. (2021). Pemahamam Materi Hak Asasi Manusia dan Perilaku Kekerasan dengan Kesadaran Hukum Siswa. Jurnal Citizenship Virtues, 1(1), 15-21.

\section{PENDAHULUAN}

Dunia pendidikan dewasa ini sungguh memprihatinkan (Wiyono, 2012). Kekerasan tidak hanya dilakukan oleh oknum guru kepada siswa tetapi kini meluas kepada sesama siswa. Ironisnya hal itu dilakukan oleh siswa, yang pada dasarnya dikenal sebagai masa-masa tumbuh kembang anak dimana dunia mereka dihiasi oleh keceriaan anak-anak, belajar dan bermain. Faktor pemicu terjadinya perilaku kekerasan maupun pelanggaran hak asasi lainnya pada anak sekolah yaitu perkembangan teknologi yang melesat hebat kemudian membawa dampak buruk bagi anak (Kusuma, 2019). Ketidakpahaman siswa tentang HAM disebabkan siswa

\footnotetext{
*Corresponding author

E-mail: yayu.pudjiastuti@gmail.com
} 
yang tidak memahami bahwa HAM yang dimiliki setiap individu dan dijamin oleh negara (Remaja, 2018), tidak mengerti bagaimana menghargai hak orang lain, bagaimana bergaul dengan teman sebaya secara baik di lingkungan sekolah. Oleh karena itu, pemahaman tentang konsep HAM sangat diperlukan untuk mendorong adanya keseimbangan antara pemahaman tentang HAM dengan kesadaran hukum akan HAM (Usman, 2015), yang diwujudkan dengan sikap dan perilaku positif terhadap perlindungan dan penegakan HAM (Triwahyuningsih, 2018; Ernis, 2018; Arifin \& Lestari, 2019).

Dalam hubungannya dengan satuan pelajaran, ranah kognitif memegang peranan paling penting. Yang menjadi tujuan pengajaran pada umumnya adalah peningkatan kemampuan siswa dalam aspek kognitif. Tingkatan pemahaman merupakan salah satu tingkatan dalam ranah kognitif yang terdiri dari enam tingkatan mulai dari yang hanya bersifat pengetahuan tentang fakta-fakta sampai kepada proses intelektual yang tinggi yaitu dapat mengevaluasikan sejumlah fakta. Aspek kognitif dibedakan atas enam jenjang yaitu pengetahuan, pemahaman, penerapan, analisis, sintesis dan penilaian (Bloom, Madaus \& Hastings, 1981; Anderson \& Krathwohl, 2010). Dengan demikian, seorang siswa dalam ranah kognitifnya dikatakan tingkat pemahamannya baik apabila siswa dapat menangkap arti dari materi yang telah ia terima menurut (Suparno, 2000).

Kecenderungan anak melakukan perilaku kekerasan menurut Purwanto \& Riyadi (2009) karena beberapa faktor: (1) faktor biologis, munculnya perilaku kekerasan akibat dorongan suatu kebutuhan dasar yang kuat; (2) faktor psikologis, sebagai hasil akumulasi frustasi yang terjadi apabila keinginan individu untuk mencapai sesuatu gagal atau terhambat; (3) faktor sosio, kultural lingkungan sosial akan mempengaruhi sikap individu dalam mengekspresikan marah. Rendahnya kesadaran seseorang terhadap hukum yang mengatur mengenai HAM adalah suatu penilaian yang tidak tahu atau paham, tidak mengerti akan sistem hukum, adanya perilaku menyimpang dari hukum, kepatuhan hukum yang rendah yang hanya mengetahui hukum tetapi berperilaku tidak sesuai dengan hukum sehingga cenderung pada tindakan pelanggaran hukum (Soekanto, 1977). Peningkatan kesadaran akan HAM berhubungan dengan tinggi rendahnya kesadaran seseorang terhadap aturan hukum yang mengatur tentang HAM. Sedangkan untuk meningkatkan kesadaran hukum seseorang diperlukan adanya peningkatan dalam pemahaman dan pengetahuan. Banyak produk hukum dan tindakan penegakkan hukum yang kurang mencerminkan nilai-nilai Pancasila, yang tersirat dengan belum dirasakannya keadilan serta rendahnya nilai moral dan akhlak di masyarakat (Pudjiastuti, 2020; Pudjiastuti, Safitri, Sutisna \& Hadi, 2020).

\section{METODE PENELITIAN}

Penelitian ini merupakan penelitian kuantitatif dengan metode korelasi (Pudjiastuti, 2004) bertujuan untuk memperoleh data empiris mengenai hubungan pemahaman tentang materi HAM dan perilaku kekerasan dengan kesadaran hukum. Penelitian ini dilaksanakan selama 3 bulan tepatnya dari bulan Juli sampai bulan September 2020 di SMK Tunas Multi Raya Depok. Jumlah sampel sebanyak 70 siswa. Instrumen yang digunakan untuk mengukur variabel Pemahaman siswa menggunakan test pilihan ganda, variabel perilaku kekerasan menggunakan angket skala perilaku dan variabel kesadaran hukum menggunakan angket skala sikap. 
Instrumen penelitian di ujicoba ke responden di luar sampel sebanyak 30 responden kemudian di uji validitas (Product Moment) dan uji reliabilitas (Alpha Cronbach), instrumen valid baru di sebar ke sampel sejumlah 70 siswa. Uji Prasyarat analisis terhadap data hasil penelitian meliputi uji normalitas, homogenitas dan linieritas. Dilanjutkan uji hipotesis; uji Signifikansi parsial untuk mengetahui hubungan antar variebel bebas dan terikat ,uji- $t$, uji- $F$ dan koefisien determinasi (Pudjiastuti, 2004; 2019).

\section{HASIL DAN PEMBAHASAN}

Berdasarkan hasil penelitian yang telah dilakukan, maka hasil penelitian disajikan dalam bentuk penyajian data yang sesuai dengan hasil pengukuran yang dilakukan.

\begin{tabular}{cccc}
\multicolumn{4}{c}{ Tabel 1. Distribusi Frekuensi Kategori Kesadaran Hukum (Y) } \\
\hline No. & Interval Kelas & Frekuensi & Persentase \\
\hline 1 & $85-95$ & 16 & 22.86 \\
2 & $96-106$ & 10 & 14,29 \\
3 & $107-117$ & 13 & 18,57 \\
4 & $118-128$ & 11 & 15,71 \\
5 & $129-139$ & 12 & 17,14 \\
6 & $140-150$ & 6 & 8,57 \\
7 & $155-165$ & 2 & 2,86 \\
\hline & Jumlah & 70 & 100 \\
\hline
\end{tabular}

Nilai pada Tabel 1 merupakan hasil pengisian kuesioner Kesadaran hukum (Y). Disimpulkan bahwa dari 70 SMK Tunas Multi Raya Depok menunjukkan bawah ada 16 orang siswa $(22,86 \%)$ memiliki kategori $85-95$, dan 10 orang siswa $(14,29 \%)$ memiliki kategori 96-106, dan 13 orang siswa $(18,57 \%)$ memiliki kategori 107-117, dan 11 orang siswa $(15,71 \%)$ memiliki kategori 118-128, dan 12 orang siswa $(17,14 \%)$ memiliki kategori $129-139,6$ orang siswa $(8,57 \%)$ memiliki kategori 140 - 150.dan 2 siswa (2,86\%) memiliki kategori 155-165.

\begin{tabular}{cccc} 
Tabel 2. Distribusi Frekuensi Kategori Perilaku Kekerasan \\
\hline
\end{tabular} \begin{tabular}{cccc} 
No. & Interval Kelas & Frekuensi & Persentase \\
\hline 1 & $67-74$ & 5 & 7,142 \\
2 & $75-82$ & 2 & 2,875 \\
3 & $83-90$ & 11 & 15,714 \\
4 & $91-98$ & 14 & 20 \\
5 & $99-106$ & 6 & 8,571 \\
6 & $107-114$ & 25 & 35,714 \\
7 & $115-122$ & 7 & 10 \\
\hline \multicolumn{5}{c}{ Jumlah } & 70 & 100 \\
\hline
\end{tabular}

Nilai pada Tabel 2 merupakan hasil pengisian kuesioner Perilaku Kekerasan (X2). Disimpulkan bahwa dari 70 SMK Tunas Multi Raya Depok menunjukkan bawah ada 5 orang siswa $(7,142 \%)$ memiliki kategori $67-74$, dan 2 orang siswa $(2,875 \%)$ memiliki kategori $75-82$, dan 11 orang siswa $(15,714 \%)$ memiliki 
kategori 83-90, dan 14 orang siswa (20,00\%) memiliki kategori 91-98, dan 6 orang siswa $(8,571 \%)$ memiliki kategori $99-106,25$ siswa(35,714\%) memiliki kategori 107-114 dan 7 siswa (10\%) memiliki kategori 115-122.

Tabel 3. Distribusi Frekuensi Kategori Pemahaman Siswa tentang HAM

\begin{tabular}{cccc}
\hline No. & Interval Kelas & Frekuensi & Persentase \\
\hline 1 & $10-12$ & 1 & 11,43 \\
2 & $13-15$ & 6 & 8,57 \\
3 & $16-18$ & 10 & 14,29 \\
4 & $19-21$ & 10 & 14,29 \\
5 & $22-24$ & 11 & 15,71 \\
6 & $25-27$ & 11 & 15,71 \\
7 & $28-30$ & 21 & 30 \\
\hline & Jumlah & 70 & 100 \\
\hline
\end{tabular}

Nilai pada Tabel 3 merupakan hasil tes Pemahaman siswa tentang HAM $\left(\mathrm{X}_{1}\right)$. Disimpulkan bahwa dari 70 SMK Tunas Multi Raya Depok menunjukkan bawah ada 1 orang siswa $(11,43 \%)$ memiliki kategori $10-12$, dan 6 orang siswa $(8,57 \%)$ memiliki kategori 16-18, dan 10 orang siswa (14,29\%) memiliki kategori 19-21, dan 10 orang siswa $(14,29 \%)$ memiliki kategori 19-21, dan 11 orang siswa $(15,71 \%)$ memiliki kategori $22-24,11$ siswa $(15,71 \%)$ memiliki kategori $25-27$,dan 21 siswa (30 \%) memiliki kategori 28-30.

Tabel 4. Uji Normalitas Data

\begin{tabular}{lccc}
\hline \multicolumn{1}{c}{ Variabel } & $L_{\text {hitung }}$ & $L_{\text {tabel }}(0,05)$ & Keterangan \\
\hline Pemahaman tentang HAM & 0,10076 & 0,1059 & Normal \\
Perilaku Kekerasan & 0,08977 & 0,1059 & Normal \\
Kesadaran Hukum & 0.09995 & 0,1059 & Normal \\
\hline
\end{tabular}

Hasil perhitungan menggunakan lilliefors variabel pemahaman materi HAM diperoleh nilai $L_{\text {hitung }}=0,10076$.Variabel Perilaku Kekerasan diperoleh hasil nilai $L_{\text {hitung }}=0,08977$. Variabel Kesadaran Hukum diperoleh nilai $L_{\text {hitung }}=0,09995$, sedangkan untuk nilai Lilliefors tabel adalah 0,1059 sehingga $L_{\text {hitung }}<L_{\text {tabel }}=0,10239<0,1059$, ketiga variabel dinyatakan berdistribusi normal.

Tabel 5. Uji Homogenitas Varians

\begin{tabular}{lccc}
\hline \multicolumn{1}{c}{ Variabel } & $\chi^{2}$ hitung & $\chi^{2}$ tabel & Keterangan \\
\hline Pemahaman siswa tentang HAM & 4,4861 & 9,4877 & Homogen \\
Perilaku Kekerasan & 8,8848 & 9,4877 & Homogen \\
Kesadaran Hukum & 4,3475 & 9,4877 & Homogen \\
\hline
\end{tabular}

Dari hasil perhitungan yang menggunakan uji Bartlet variabel pemahaman materi HAM diperoleh nilai $\chi_{\text {hitung }}^{2}=4,4861$. Variabel perilaku kekerasan diperoleh nilai $\chi_{\text {hitung }}^{2}=8,8848$. Variabel kesadaran hukum diperoleh nilai $\chi^{2}{ }_{\text {hitung }}=4,3475$ sedangkan untuk nilai $\chi_{\text {tabel }}^{2}=9,4877$ sehingga $\chi_{\text {hitung }}^{2} \leq \chi_{\text {tabel }}^{2}=4,3475<9,4877$ , dinyatakan ketiga variabel mempunyai data homogen. 


\begin{tabular}{|c|c|c|c|}
\hline Variabel & $F_{\text {hitung }}$ & $F_{\text {tabel }}$ & Ket. \\
\hline $\begin{array}{l}\text { Pemahaman Siswa tentang HAM (X1) dan Kesadaran } \\
\text { Hukum (Y) }\end{array}$ & 0,200 & 3,134 & Linear \\
\hline Perilaku Kekerasan $\left(\mathrm{X}_{2}\right)$ dan Kesadaran Hukum $(\mathrm{Y})$ & 0,027 & 3,134 & Linear \\
\hline $\begin{array}{l}\text { Pemahaman Siswa tentang HAM }\left(\mathrm{X}_{1}\right) \text { dan Perilaku } \\
\text { Kekerasan }\left(\mathrm{X}_{2}\right) \text { Bersama-sama Memiliki hubungan } \\
\text { dengan Kesadaran Hukum }(\mathrm{Y})\end{array}$ & 0,227 & 3,134 & Linear \\
\hline
\end{tabular}

Hasil uji linieritas regresi variabel pemahaman HAM diperoleh hasil $F_{\text {hitung }}=0,200$. variabel perilaku kekerasan diperoleh $F_{\text {hitung }}=0.027$ dan variabel kesadaran hukum diperoleh $F_{\text {hitung }}=0,227$. Hasil tersebut kemudian dikonsultasikan dengan $F_{\text {tabel }}=3,134(\alpha=0,05)$ dinyatakan ketiga variabel mempunyai data linier /signifikan.

Tabel 7. Uji- $t$

\begin{tabular}{lccc}
\hline \multicolumn{1}{c}{ Variabel } & $t_{\text {hitung }}$ & $t_{\text {tabel }}$ & Ket \\
\hline $\begin{array}{l}\text { Pemahaman siswa tentang HAM }\left(\mathrm{X}_{1}\right) \text { dan } \\
\text { Kesadaran Hukum }(\mathrm{Y})\end{array}$ & 27,467 & 1,995 & Signifikan \\
$\begin{array}{l}\text { Perilaku Kekerasan }\left(\mathrm{X}_{2}\right) \text { dan Kesadaran } \\
\text { Hukum(Y) }\end{array}$ & 11,585 & 1,995 & Signifikan \\
$\begin{array}{l}\text { Pemahaman siswa tentang HAM }\left(\mathrm{X}_{1}\right) \text { dan } \\
\text { Perilaku Kekerasan }\left(\mathrm{X}_{2}\right) \text { Bersama-Sama dengan }\end{array}$ & 28,185 & 1,995 & Signifikan \\
Kesadaran Hukum (Y) & & & \\
\hline
\end{tabular}

Hasil perhitungan uji-t variabel $X_{1}$ terhadap $Y$ diperoleh thitung sebesar 27,467 , variabel $\mathrm{X}_{2}$ terhadap $\mathrm{Y}$ diperoleh $t_{\text {hitung }}=11,585$, variabel X1 dan X2 bersama-sama dengan Y diperoleh $t_{\text {hitung }}=28,185$ Hasil tersebut kemudian dikonsultasikan dengan $t_{\text {tabel }}=1,995(\alpha=0,05)$ Hal itu menunjukkan bahwa $t_{\text {hitung }} \geq t_{\text {tabel }}$, dinyatakan data signifikan.

Tabel 8. Uji- $F$

\begin{tabular}{lccc}
\hline \multicolumn{1}{c}{ Variabel } & $F_{\text {hitung }}$ & $F_{\text {tabel }}$ & Ket \\
\hline $\begin{array}{l}\text { Pemahaman siswa tentang HAM }\left(\mathrm{X}_{1}\right) \text { dan } \\
\text { Perilaku Kekerasan }\left(\mathrm{X}_{2}\right) \text { Bersama-Sama dengan }\end{array}$ & 391,368 & 3,13 & Signifikan \\
Kesadaran Hukum $(\mathrm{Y})$ & & & \\
\hline
\end{tabular}

Hasil Uji- $F$ menyatakan bahwa variabel pemahaman siswa tentang HAM dan perilaku kekerasan bersama sama dengan variabel kesadaran hukum diperoleh nilai $F_{\text {hitung }}=391,368$ kemudian di konsultasikan dengan $F_{\text {tabel }}=3,13$ dan dinyatakan signifikan karena $F_{\text {hitung }}$ lebih dari $F_{\text {tabel }}$

Tabel 9. Uji Koefisien Determinasi

\begin{tabular}{ccccc}
\hline Model & $R$ & $R$ Square & Adjusted $R$ Square & Std. Error of the Estimate \\
\hline 1 &, $960^{\mathrm{a}}$ &, 921 &, 919 & 5,34681
\end{tabular}

Predictors: (Constant), pemahaman HAM, perilaku kekerasan 
Dari Tabel 9, didapatkan nilai Adjusted $R$ Square (koefisien determinasi) sebesar 0,919 yang artinya ada hubungan variabel indefenden $\left(\mathrm{X}_{1}\right.$ dan $\left.\mathrm{X}_{2}\right)$ terhadap variabel $\mathrm{Y}$ sebesar 91,9 \%.Merujuk pada hasil perhitungan dan analisis data penelitian, terlihat ada hubungan yang signifikan antara pemahaman siswa tentang HAM dan perilaku kekerasan dengan kesadaran hukum.

\section{KESIMPULAN}

Hasil penelitian menunjukan terdapat korelasi hubungan signifikan antara pemahaman siswa tentang HAM dan perilaku kekerasan dengan Kesadaran Hukum dilakukan dengan analisis korelasi ganda. Hasil analisis untuk mengetahui korelasi hubungan signifikan antara pemahaman siswa tentang HAM dan perilaku kekerasan dengan Kesadaran Hukum, maka diperoleh $r_{\text {hitung }}=0,9598$ Hasil tersebut kemudian dikonsultasikan dengan $r_{\text {tabel }}=0.2352(\alpha=0,05$ dan $\mathrm{N}=70)$. Hasil konsultasi tersebut menunjukan bahwa $r_{\text {hitung }} \geq r_{\text {tabel }}, 0,9598 \geq 0,2352$. Hal ini menunjukan bahwa ada hubungan signifikan pemahaman siswa tentang HAM dan perilaku kekerasan dengan kesadaran hukum pada 70 siswa kelas X SMK Tunas Multi Raya Depok. Dari perhitungan koefisien determinan (KD) diketahui bahwa hubungan Pemahaman materi HAM dan perilaku kekerasan dengan Kesadaran Hukum adalah sebesar $91,9 \%$ sedangkan 8,1 ditentukan oleh faktor lain

\section{REFERENSI}

Anderson, L. W., \& Krathwohl, D. R. (2010). Kerangka Landasan untuk Pembelajaran, Pengajaran, dan Asesmen. Yogyakarta: Pustaka Pelajar.

Arifin, R., \& Lestari, L. E. (2019). Penegakan dan Perlindungan Hak Asasi Manusia di Indonesia dalam Konteks Implementasi Sila Kemanusiaan yang Adil dan Beradab. Jurnal Komunikasi Hukum (JKH), 5(2), 12-25.

Bloom, B. S., Madaus, G. F., \& Hastings, J. T. (1981). Evaluation to Improve Learning. USA: McGraw-Hill.

Ernis, Y. (2018). Implikasi Penyuluhan Hukum Langsung terhadap Peningkatan Kesadaran Hukum Masyarakat. Jurnal Penelitian Hukum De Jure, 18(4), 477496.

Kusuma, R. A. (2019). Dampak Perkembangan Teknologi Informasi dan Komunikasi terhadap Perilaku Intoleransi dan Antisosial di Indonesia. Mawa'izh: Jurnal Dakwah Dan Pengembangan Sosial Kemanusiaan, 10(2), 273-290.

Pudjiastuti. S. R. (2004). Metode Penelitian Pendidikan. Jakarta: STKIP Kusuma Negara.

Pudjiastuti, S. R. (2019). Penelitian Pendidikan. Yogyakarta: Media Akademi.

Pudjiastuti, S. R. (2020). Internalisasi Nilai-Nilai Pancasila Dalam Mencegah Paham Radikal. Jurnal Ilmiah Mimbar Demokrasi, 19(02), 32-39.

Pudjiastuti, S. R., Safitri, R., Sutisna. M., \& Hadi, N. (2020). Utilization of Forest Natural Resource Potentials, Especially Wood, to Realize Independence of Regional Development. Journal of Advanced Research in Dynamical and Control Systems, 12(2), 1720-1724.

Purwanto, T., \& Riyadi, S. (2009). Asuhan Keperawatan Jiwa. Yogyakarta: Graha Ilmu. 
Remaja, I. N. G. (2018). Penerapan Asas Praduga Tak Bersalah Bagian dari Perlindungan Hak Asasi Manusia yang Harus Dijamin oleh Negara. Kertha Widya, 6(1), 8-19.

Soekanto, S. (1977). Kesadaran Hukum dan Kepatuhan Hukum. Jurnal Hukum \& Pembangunan, 7(6), 462-470.

Suparno, A. S. (2000). Membangun Kompetensi Belajar. Jakarta: Direktorat Jenderal Pendidikan Tinggi.

Triwahyuningsih, S. (2018). Perlindungan dan Penegakan Hak Asasi Manusia (HAM) di Indonesia. Legal Standing: Jurnal Ilmu Hukum, 2(2), 113-121.

Usman, A. H. (2015). Kesadaran Hukum Masyarakat Dan Pemerintah Sebagai Faktor Tegaknya Negara Hukum Di Indonesia. Jurnal Wawasan Yuridika, 30(1), 26-53.

Wiyono, H. (2012). Pendidikan karakter dalam bingkai pembelajaran di sekolah. CIVIS, 2(2), 1-18. 